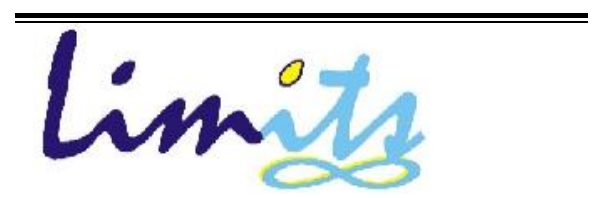

J. Math. and Its Appl.

ISSN: $1829-605 \mathrm{X}$

Vol. 13, No. 1, Mei 2016, 49-58

\title{
TRANSFORMASI MP-WAVELET TIPE B DAN APLIKASINYA PADA PEMAMPATAN CITRA
}

\author{
Kistosil Fahim ${ }^{1}$, Mahmud Yunus², Suharmadi ${ }^{3}$ \\ ${ }^{1}$ Jurusan Matematika, FMIPA, ITS, Surabaya, kfahim@matematika.its.ac.id \\ ${ }^{2}$ Jurusan Matematika, FMIPA, ITS, Surabaya, yunusm@matematika.its.ac.id \\ ${ }^{3}$ Jurusan Matematika, FMIPA, ITS, Surabaya, susan@matematika.its.ac.id
}

\begin{abstract}
Abstrak
Sekarang ini banyak dikembangkan metode penyelesaian masalah secara komputasi. Pada penelitian ini dikonstruksi suatu transformasi wavelet menggunakan operator dalam aljabar max-plus yang disebut sebagai MPWavelet. Hasil konstruksi ini secara komputasi membutuhkan waktu yang lebih cepat daripada transformasi wavelet pada umumnya. Pada konstruksi ini dihasilkan satu tipe MP-Wavelet yang disebut dengan MP-Wavelet tipe B. MP-Wavelet tipa ini merupakan pengembangan dari penelitian Fahim yang dipublikasikan pada "Seminar Nasional Pendidikan Sains Tahun 2014" dan "Konferensi Nasional Matemtika 17". Tipe B ini digunakan untuk pemampatan citra. Untuk melihat hasil rekonstruksi pada proses pemampatan citra "Lena". Dari simulasi pemampatan ini didapatkan bahwa MP-Wavelet tipe B ini menghasilkan rekonstruksi citra yang lebih baik daripada tipe I yang dikonstruksi oleh Nobuhara (2010); dan tipe I serta tipe A Fahim (2014). Katakunci: Aljabar Max-plus, Transformasi Wavelet
\end{abstract}

\section{Pendahuluan}

Saat ini telah banyak dikembangkan metode untuk menyelesaikan masalah secara komputasi. Namun kebanyakan metode menggunakan operasi perkalian yang membutuhkan biaya komputasi yang cukup besar. Untuk itu dalam hal ini akan dikembangkan suatu metode penyelesaian masalah dengan hanya menggunakan operasi maksimum dan penjumlahan yaitu transformasi wavelet menggunakan aljabar max-plus (MP-Wavelet).

Dilihat dari sifat kelinierannya transformasi wavelet mempunyai sifat linier tetapi operator penjumlahan (addition/maksimum) dalam aljabar maxplus merupakan operator nonlinier. Sehingga dalam penelitian ini transformasi yang terbentuk merupakan 
transformasi yang nonlinier (metode nonlinier). Dari berbagai literatur mengenai metode nonlinier yang telah dikembangkan berdasarkan struktur yang berbeda[5,6], tidak satupun yang memenuhi semua kasus yang disebutkan di atas.

Wavelet morfologi yang merupakan salah satu jenis transformasi wavelet yang nonlinier akhir-akhir ini dikemukakan oleh Heijmans[2,3]. Namun wavelet morfologi didefinisikan berdasarkan aljabar ordinal pada bilangan real $\mathbb{R}$, bersama dengan empat operasi aritmatika yang dilengkapi dengan maksimum dan minimum yang tentunya sangat menyulitkan. Selain wavelet morfologi ada juga wavelet yang nonlinier yaitu MP-Wavelet. MP-Wavelet ini telah dibahas oleh Nobuhara dalam papernya[7] yang isinya merupakan generalisasi ke arah baru dari Haar morfologi wavelet yang diusulkan oleh Heijmans, yakni menghilangkan operasi perkalian dan perhitungan floating point dalam pendekatannya. Tetapi Nobuhara tidak menjelaskan secara eksplisit transformasi MP-Wavelet yang dia dapatkan. Kemudian pada tahun 2013 Kistosil Fahim [4] mengkonstruksi MP-Wavelet tipe I dan pada tahun 2014 Kistosil Fahim [8] mengkonstruksi MP-Wavelet tipe A. Dalam penelitian ini melanjutkan penelitian Kistosil Fahim pada tahun 2013 dan 2014 tersebut yaitu mengkonstruksi transformasi MP-Wavelet menggunakan operator pada aljabar maxplus.

\section{TINJAUAN PUSTAKA}

Pada aljabar max-plus hanya digunakan dua operator yaitu operator maksimum (oplus) dan plus (otimes). Dalam bukunya[9] mendefinisikan struktur aljabar $\left(\mathbb{R}_{\varepsilon}, \oplus, \otimes\right)$ dengan $\mathbb{R}_{\varepsilon}=\mathbb{R} \cup\{\varepsilon\}$ dan $\varepsilon=\infty$. Dan definisi operasi dari operator-operatornya diuraikan sebagai berikut, untuk semua $x, y$ anggota $\mathbb{R}_{\varepsilon}$ maka $x \otimes y=\max \{x, y\}$ dan $x \otimes y=x+$ $y$.

Dengan definisi diatas didapatkan bahwa $\left(\mathbb{R}_{\varepsilon}, \oplus, \otimes\right)$ merupakan semi-ring dengan elemen netral $\varepsilon$ dan elemen satuan 0[9]. Dalam penelitian ini cukup digunakan $\mathbb{Z}_{\varepsilon}=\mathbb{Z} U$ $\{\varepsilon\}$ tidak perlu $\mathbb{R}_{\varepsilon}$, sehingga dalam komputasi jauh lebih efisien. Dapat dilihat sifat aljabar dari $\left(\mathrm{Z}_{\varepsilon}, \oplus, \otimes\right)$ sama dengan di $\left(\mathrm{R}_{\varepsilon}, \oplus, \otimes\right)$, yakni $\left(\mathrm{Z}_{\varepsilon}, \oplus, \otimes\right)$ masih merupakan semi-ring. Dengan demikian penyempitan himpunan domain ini tidak begitu berpengaruh pada proses analisisnya.

Wavelet pada matematika adalah sebuah fungsi untuk mendapatkan basis yang disesuaikan dengan syarat-syarat tertentu sehingga berguna dalam aplikasi tertentu. Transformasi wavelet dapat juga dikatakan transformasi perbaikan dari transformasi Fourier. Dalam bukunya Yunus [11] menjelaskan bahwa transformasi wavelet dibagi menjadi transformasi wavelet kontinu dan transformasi wavelet diskrit. Kemudian dalam bukunya Xiang [10] menjelaskan bahwa transformasi wavelet diskrit yang dilakukan berulang-ulang dapat mendekomposisikan sinyal menjadi sebuah sinyal hampiran beresolusi rendah dan barisan sinyal detil yang beresolusi lebih tinggi. Lebih jelasnya dapat dilihat pada Gambar 1. 


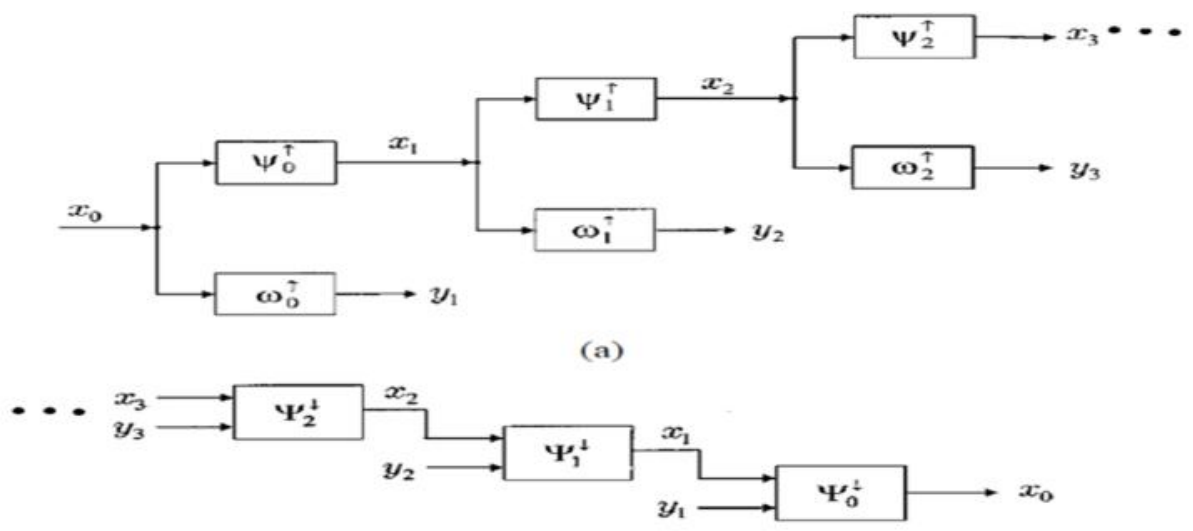

(b)

Gambar 1: Bagan dekomposisi sinyal dengan transformasi wavelet (a) operator analisis (b) operator sinpenelitian

Misalkan diberikan sinyal input $\mathrm{x}_{\mathrm{U}}$, yang berupa gambar, suara maupun pola. Sinyal ini didekomposisikan menggunakan transformasi wavelet sehingga didapat sinyal hampiran dinotasikan sebagai $\mathrm{x}_{1}$ dan sinyal detail dinotasikan sebagai $\mathrm{y}_{1}$. Selanjutnya, sinyal $x_{1}$ tersebut juga didekomposisikan kedalam $x_{2}$ dan $y_{2}$. Transformasi ini dilakukan terus menerus sampai dekomposisi ke- $j$, yang hasilnya didapat $x_{J}$ dan $y_{j}$. Secara umum proses ini dapat ditulis dalam bentuk

$$
x_{0} \rightarrow\left\{x_{1}, y_{1}\right\} \rightarrow\left\{x_{2}, y_{2}, y_{1}\right\} \rightarrow \cdots \rightarrow\left\{x_{j}, y_{j}, y_{j-1}, \cdots, y_{1}\right\}
$$

Heijmans dalam penelitiannya [2,3] menjelaskan bahwa wavelet morfologi adalah bentuk transformasi wavelet menggunakan operator aljabar max atau min[10]. Dalam penelitiannya ini dia menjelaskan dua skema dalam dekomposisi wavelet yaitu coupled wavelet decomposition (skema yang digunakan pada penelitian ini) dan uncoupled wavelet decomposition. Dalam skema coupled wavelet decomposition, dia menjelaskan bahwa terdapat dua analisis operator, satu untuk signal $\left(\psi_{j}^{\uparrow}\right)$ dan satu untuk detail $\left(\omega_{j}^{\uparrow}\right)$ dan satu operator sinpenelitian $\left(\Psi_{J}^{\downarrow}\right)$. Dengan pemetaan operatornya adalah sebagai berikut

$\psi_{j}^{\uparrow}: V_{j} \rightarrow V_{j+1}$

$\omega_{j}^{\uparrow}: V_{J} \rightarrow W_{J+1}$

$\Psi_{j}^{\downarrow}: V_{j+1} \times W_{j+1} \rightarrow V_{j}$

Dengan $j=0,1,2, \cdots$ dan $V_{j}, W_{j}$ menyatakan ruang sinyal. Selain itu operator tersebut harus memenuhi syarat-syarat sebagai berikut

$\Psi_{j}^{\downarrow}\left(\psi_{j}^{\uparrow}\left(x_{j}\right), \omega_{j}^{\uparrow}\left(x_{j}\right)\right)=x_{j}$, untuk $x_{j} \in V_{j}$

$\psi_{j}^{\uparrow}\left(\Psi_{j}^{\downarrow}\left(x_{j+1}, y_{j+1}\right)\right)=x_{j+1}$, untuk $x_{j+1} \in V_{j+1}$

$\omega_{j}^{\uparrow}\left(\Psi_{j}^{\downarrow}\left(x_{j+1}, y_{j+1}\right)\right)=y_{j+1}$, untuk $y_{j+1} \in W_{j+1}$

Dari dasar matematika morfologi yang dikemukakan oleh Heijmans[2] diatas, Nobuhara[7] mengkonstruksi transformasi MP-Wavelet. Namun dalam papernya dia hanya menuliskan transformasinya saja, tanpa menjelaskan secara terperinci penurunan formulasi transformasi MP-Wavelet yang dia dapat. Karena itu dalam penelitian Dinarina[1] berusaha menjelaskan transformasi ini secara analitik, namun dia mengalami kendala dengan adanya floating point. Dengan adanya permasalahan ini dalam penelitian ini akan diuraikan secara analitik mengenai MP-Wavelet dan akan dianalisis sifat-sifat yang ada pada transformasi MP-Wavelet dalam pengolahan citra digital.

Pada penelitian Nobuhara[7] dikonstruksi dua tipe MP-Wavelet yang disebut dengan MP-Wavelet tipe I dan tipe II. Pada papernya Nobuhara mengimplementasikan MPWavelet yang telah dikonstruksi pada proses pemampatan citra. Namun sebelum masuk ke 
proses tersebut Nobuhara terlebih dahulu memperlihatkan hasil dekomposisi citra dengan menggunakan sampling window $2 \times 2$. Dari hasil simulasi pada pemampatan citra, Nobuhara menyimpulkan bahwa MP-Wavelet tipe II menghasilkan rekonstruksi citra lebih baik daripada rekonstruksi citra dengan menggunakan MP-Wavelet tipe I. Namun wavelet Haar masih menghasilkankan rekonstruksi lebih baik daripada kedua tipe tersebut.

Pada penelitian ini juga dilakukan simulasi pemampatan citra dengan menggunakan MP-Wavelet hasil konstruksi dari penelitian ini. Pada tahap simulasi dari penelitian ini digunakan komputer dengan spesifikasi RAM 2GB, OS 64 byte, processor Intel Celeron dan dengan CPU 1000M. Kemudian pada pemampatan citra ini terdapat proses penerapan zero thresholding.

\section{Hasil Dan Pembahasan}

Pada bagian ini akan dilakukan konstruksi MP-Wavelet dan selanjutnya dilakukan analisis sifat-sifat MP-Wavelet dari hasil konstruksi dengan melakukan serangkaian simulasi pada pemampatan. Berikut pembahasan mengenai konstruksi MP-Wavelet.

\subsection{Konstruksi Transformasi Wavelet}

Pada bagian ini dilakukan konstruksi MP-Wavelet. Ide dasar konstruksi ini adalah dua persamaan yang berlaku dalam operasi aljabar max-plus, yaitu

$(a \oplus b) \oslash[(a \oslash b) \oplus 0]=b$

$\left(\bigoplus_{i=1}^{p} a_{i} \oplus b\right) \oslash\left[\bigoplus_{i=1}^{p}\left(a_{i} \oslash b\right) \oplus b\right]=b$

\section{MP-Wavelet tipe B dengan $\boldsymbol{p}$ kanal}

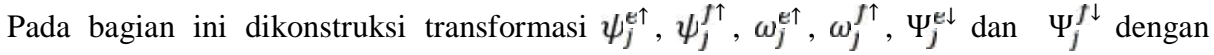
pemetaannya adalah $\psi_{j}^{e \uparrow}: V_{J} \rightarrow V_{\jmath+1}, \psi_{j}^{f \uparrow}: V_{\jmath+1} \times W_{\jmath+1} \rightarrow V_{J+1}, \omega_{j}^{e \uparrow}: V_{\jmath} \rightarrow W_{\jmath+1}, \omega_{j}^{f \uparrow}: V_{j+1} \times$ $W_{j+1} \rightarrow W_{j+1}, \quad \Psi_{j}^{e \downarrow}: V_{j+1} \times W_{j+1} \rightarrow V_{j+1} \times W_{j+1}, \Psi_{j}^{e \downarrow}: V_{j+1} \times W_{j+1} \rightarrow V_{j}$. Dengan $V_{j}$ merupakan ruang sinyal $\mathbb{Z}_{j}$ ke $\mathbb{Z}_{j}$ dan $W_{j}$ merupakan ruang sinyal $\mathbb{Z}_{+1 j}$ ke $\mathbb{Z}_{j}^{p-1}$ dan juga $j$ merupakan bilangan bulat tak negatif. Untuk lebih jelasnya dapat dilihat pada Gambar 2.

Pada Gambar 2 terlihat bahwa input dari $\psi_{j}^{e \uparrow}$ merupakan sinyal $x_{j}$ dan outputnya adalah $x_{j+1}$. Dan pada (Gambar 2) terlihat bahwa input $\omega_{j}^{e \uparrow}$ merupakan sinyal $x_{j}$ dan outputnya adalah $y_{j+1,1}, y_{j+1,2}, \cdots, y_{j+1, p-1}$. Berdasarkan hal tersebut disusun operator analisis sebagai berikut:

$$
\begin{aligned}
\psi_{j}^{e \uparrow}\left(x_{j}\right)[n] & =\bigoplus_{i=U}^{p-1} x_{j}[p+k]=x_{j+1}^{\prime}[n] \\
\omega_{j}^{{ }^{\uparrow}}\left(x_{j}\right)[n] & =y_{j+1}^{\prime}[n] \\
& =\left(y_{j+1,1}^{\prime}[n], y_{j+1,2}^{\prime}[n], \cdots, y_{j+1, p-1}^{\prime}[n]\right) \\
& =\left(\omega_{j, 1}^{e \uparrow}\left(x_{j}\right)[n], \omega_{j, 2}^{e \uparrow}\left(x_{j}\right)[n], \cdots, \omega_{j, p-1}^{e \uparrow}\left(x_{j}\right)[n]\right),
\end{aligned}
$$

dengan

$$
\omega_{j, r}^{e \uparrow}\left(x_{\jmath}\right)[n]=x_{j}[p+r] \oslash x_{j}[p]=y_{j+1, I}^{\prime}[n] .
$$



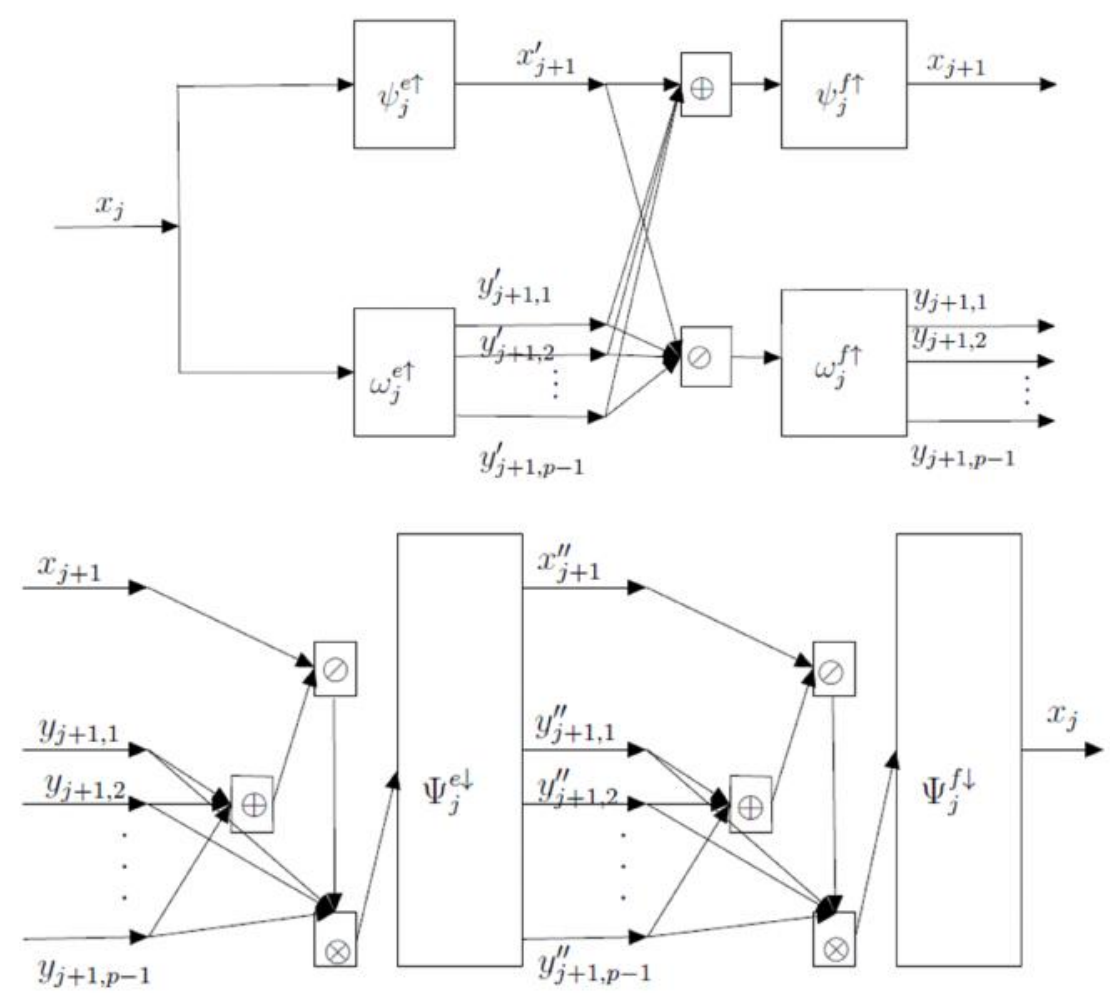

Gambar 2. Bagan dekomposisi sinyal dengan transformasi MP-Wavelet Tipe B dengan $\boldsymbol{p}$ kanal (a) operator analisis (b) operator sintesis

Pada (Gambar 2) terlihat bahwa input dari $\psi_{j}^{J \uparrow}$ merupakan sinyal $x_{j+1}^{\prime}$ dan $y_{j+1,1}^{\prime}, y_{j+1,2}^{\prime}, \cdots, y_{j+1, p-1}^{\prime}$ dan outputnya adalah $x_{j+1}$ yaitu merupakan sinyal hampiran. Dan pada Gambar 2 terlihat bahwa input dari $\omega_{j}^{j \uparrow}$ merupakan sinyal $x_{j+1}^{\prime}$ dan $y_{j+1,1}^{\prime}, y_{j+1,2}^{\prime}, \cdots, y_{j+1, p-1}^{\prime}$ dan outputnya adalah $y_{j+1,1}, y_{j+1,2}, \cdots, y_{j+1, p-1}$ yang merupakan sinyal detil. Berdasarkan hal tersebut disusun operator analisis sebagai berikut:

$\psi_{j}^{j^{\uparrow}}\left(x_{j+1}^{\prime}, y_{j+1}^{\prime}\right)[n]=x_{j+1}[n]=x_{j+1}^{\prime}[n]$

$\omega_{j}^{J \uparrow}\left(x_{j+1}^{\prime}, y_{j+1}^{\prime}\right)[n]=y_{j+1}[n]$

$$
=\left(y_{j+1,1}[n], y_{j+1,2}[n], \cdots, y_{j+1, p-1}[n]\right)
$$

$=\left(\omega_{j, 1}^{J \uparrow}\left(x_{j+1}^{\prime}, y_{j+1}^{\prime}\right)[n], \omega_{j, 2}^{J \uparrow}\left(x_{j+1}^{\prime}, y_{j+1}^{\prime}\right)[n], \cdots, \omega_{j, p-1}^{j \uparrow}\left(x_{j+1}^{\prime}, y_{j+1}^{\prime}\right)[n]\right)(9)$

dengan

$\omega_{j, 1}^{f \uparrow}\left(x_{j+1}^{\prime}, y_{j+1}^{\prime}\right)[n]=\bigoplus_{k=1}^{p-1} y_{j+1, k}^{\prime}[n]=y_{j+1,1}[n]$

$\omega_{j, r}^{f \uparrow}\left(x_{j+1}^{\prime}, y_{j+1}^{\prime}\right)[n]=y_{j+1, r}^{\prime}[n] \oslash y_{j+1,1}^{\prime}[n]=y_{j+1, r}[n], r=2,3, \cdots, p-1$

Pada (Gambar 2) terlihat bahwa input dari $\Psi_{j}^{e \downarrow}$ terdiri dari dua bagian yaitu sinyal hampiran $x_{j+1}$ dan detil $y_{j+1,1}, y_{j+1,2}, \cdots, y_{j+1, p-1}$ dan outputnya adalah $x_{j+1}^{\prime \prime}$ dan $y_{j+1,1}^{\prime \prime}, y_{j+1,2}^{\prime}, \cdots, y_{j+1, p-1}^{\prime \prime}$. Berdasarkan hal tersebut disusun operator sintesis sebagai berikut:

$\Psi_{j}^{€ \uparrow}\left(x_{j+1}, y_{j+1}\right)[n]=\left(x_{j+1}^{\prime}[n], y_{j+1}^{\prime \prime}[n]\right)$ 


$$
\begin{aligned}
& =\left(y_{j+1,1}[n], y_{j+1,2}[n], \cdots, y_{j+1, p-1}[n]\right) \\
& =\left(x_{j+1},\left(\Psi_{j, 1}^{\in \downarrow}\left(x_{j+1}, y_{j+1}\right)[n], \Psi_{j, 2}^{\in \downarrow}\left(x_{j+1}, y_{j+1}\right)[n], \cdots, \Psi_{j, p-1}^{e \downarrow}\left(x_{j+1}, y_{j+1}\right)[n]\right)\right.
\end{aligned}
$$

dengan

$$
\begin{aligned}
& \Psi_{j, 1}^{e \downarrow}\left(x_{j+1}, y_{j+1}\right)[n]=y_{j+1,1}[n] \oslash\left(\bigoplus_{k-2}^{p-1} y_{j+1, k}[n] \oplus 0\right) \\
& \Psi_{j, r}^{e \downarrow}\left(x_{j+1}, y_{j+1}\right)[n]=\Psi_{j, 1}^{e \downarrow}\left(x_{j+1}, y_{j+1}\right)[n] \otimes y_{j+1, r}[n], r=2,3, \cdots, p-1
\end{aligned}
$$

Pada (Gambar 2) terlihat bahwa input dari $\Psi_{j}^{f \downarrow}$ terdiri dari dua bagian yaitu sinyal hampiran $x_{j+1}^{\prime \prime}$ dan detil $y_{j+1,1}^{\prime \prime}, y_{j+1,2}^{\prime \prime}, \cdots, y_{j+1, p-1}^{\prime \prime}$ dan outputnya adalah $x_{j}$. Berdasarkan hal tersebut disusun operator sintesis sebagai berikut:

$$
\begin{aligned}
& \Psi_{j}^{J \downarrow}\left(x_{j+1}^{\prime \prime}, y_{j+1}^{\prime \prime}\right)[p]=x_{j+1}^{\prime \prime}[n] \oslash\left(\bigoplus_{k-1}^{p-1} y_{j+1, k}^{\prime \prime}[n] \oplus 0\right) \\
& \Psi_{j}^{f \downarrow}\left(x_{j+1}^{\prime \prime}, y_{j+1}^{\prime \prime}\right)[p+r]=\Psi_{j}^{\ell \downarrow}\left(x_{j+1}^{\prime \prime}, y_{j+1}^{\prime \prime}\right)[p] \otimes y_{j+1, I}^{\prime \prime}[n], r=2,3, \cdots, p-1
\end{aligned}
$$

Dengan $x_{j}, x_{j}^{\prime}, x_{j}^{\prime \prime} \in V_{j}, x_{j+1}, x_{j+1}^{\prime}, x_{j+1}^{\prime} \in V_{j+1}$ dan $y_{j+1}, y_{j+1}^{\prime}, y_{j+1}^{\prime \prime} \in W_{j+1}$. Berdasarkan konstruksi transformasi diatas (Persamaan 9, 10, 11, 12, 13, 14), berikut disusun suatu proposisi mengenai transformasi wavelet.

Proposisi 1. Operator analisis dan sintesis yang didefinisikan sebagai $\psi_{j}^{\uparrow}=\psi_{j}^{l^{\uparrow}}$ 。 $\psi_{j}^{u \uparrow}, \omega_{j}^{\uparrow}=\omega_{j}^{j \uparrow} \circ \omega_{j}^{u \uparrow}$ dan $\Psi_{j}^{\downarrow}=\Psi_{j}^{j \downarrow} \circ \Psi_{j}^{e \downarrow}$ dengan $\psi_{j}^{u \uparrow}=\left(\psi_{j}^{\mathrm{e}}, \psi_{j}^{\mathrm{e} \uparrow}\right)$ dan operator $\psi_{j}^{\mathrm{e}}, \psi_{j}^{j \uparrow}$, $\omega_{j}^{€ \uparrow}, \omega_{j}^{f \uparrow}, \Psi_{j}^{e \downarrow}$ dan $\Psi_{j}^{f \downarrow}$ pada Persamaan (6), (7), (8). (9), (10), (11) dan (12) merupakan transformasi wavelet yaitu memenuhi Persamaan (1), (2) dan (3).

\subsection{Simulasi Pemampatan Citra Menggunakan MP-Wavelet}

Pada bagian ini dibagi menjadi tiga subbagian yaitu yang pertama simulasi dekomposisi dari citra kemudian yang kedua kegunaan MP-Wavelet pada pemampatan citra. Selanjutnya yang terakhir adalah analisis running time pada setiap tipe MP-Wavelet. Untuk lebih jelasnya dapat dilihat pada uraian berikut.

\subsubsection{Penggunaan MP-Wavelet Pada Pemampatan Citra}

Pada bagian ini dilakukan simulasi pada pemampatan citra. Simulasi ini menggunakan citra gray scale yaitu citra "lena". Pada tahap simulasi ini citra tersebut dirubah nilai bppnya yaitu mulai dari 1 sampai dengan 8 dengan penambahan bppnya sebesar $7 \times 10^{-3}$ sehingga tiap jenis citra dirubah menjadi sebanyak 1000 citra yang berbeda dalam hal nilai bppnya. Kemudian hasil simulasi dari citra dihitung PSNR untuk setiap nilai bpp, sehingga didapatkan nilai PSNR untuk setiap nilai bpp. Hasil perhitungan ini yang akan diplotkan untuk melihat sifat dari tiap tipe MP-Wavelet pada pemampatan citra.

Berdasarkan hasil simulasi paga Gambar 3 dapat disimpulkan bahwa untuk MPWavelet tipe B hasil terbaik terjadi ketika sampling window $2 \times 2$ dan bpp lebih besar dari 5. Sehingga dari hasil ini dapat direkomendasikan bahwa untuk MP-Wavelet tipe B ini bisa digunakan untuk pemampatan citra dengan hanya menggunakan $b p p=5$.

Kemudian dilakukan simulasi dengan membandingkan hasil rekonstruksi dari MPWavelet tipe B, MP-Wavelet tipe I dan tipe A yang dikonstruksi oleh Fahim, dan MPWavelet tipe I yang dikonstruksi oleh Nobuhara. Untuk perbandingan hasilnya dapat dilihat pada Gambar 4. 
Berdasarkan Gambar 4 terlihat bahwa MP-Wavelet tipe B yang telah dikonstruksi pada penelitian ini menghasilkan rekonstruksi citra lebih baik daripada rekonstruksi menggunakan MP-Wavelet tipe I oleh Nobuhara dan Fahim. Untuk hasil rekonstruksi citra dapat dilihat pada Gambar 5, yaitu secara visual hasil rekonstruksi tersebut tidak ada perbedaan dengan citra awal.

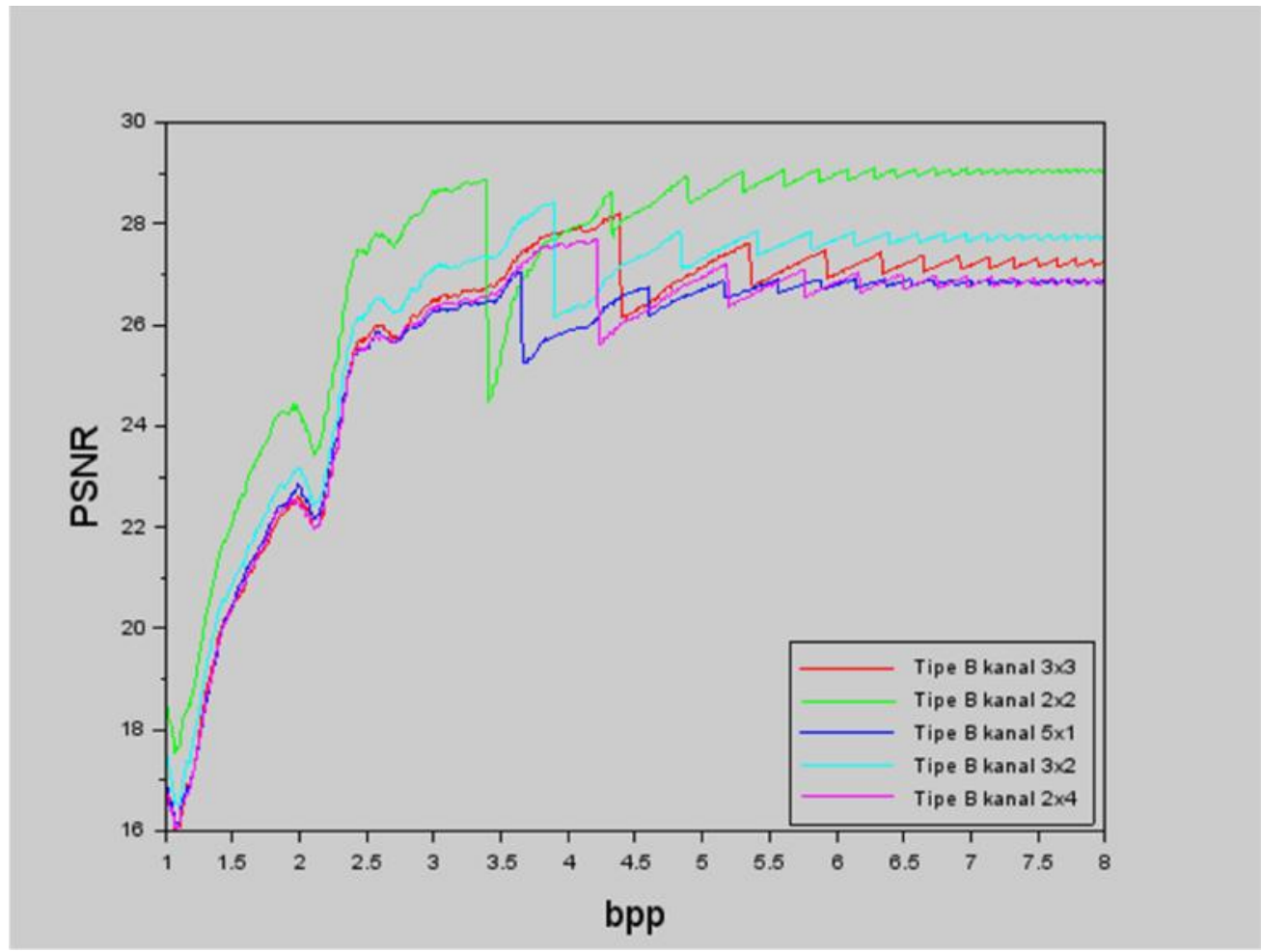

Gambar 3. Grafik bpp-PSNR dari citra "lena" sebagai perbandingan hasil pemampatan antar MP-Wavelet tipe B berdasarkan ukuran sampling window. 




Gambar 4. Grafik bpp-PSNR citra "lena" sebagai perbandingan hasil pemampatan antar MP-Wavelet tipe B dan MP Wavelet tipe I dan tipe A dari Fahim dan Nobuhara, 2010.

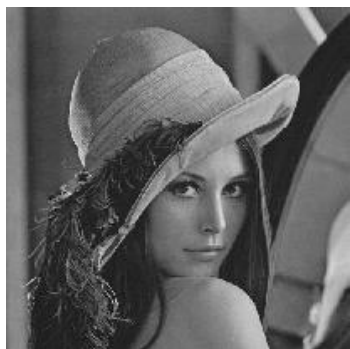

(a)

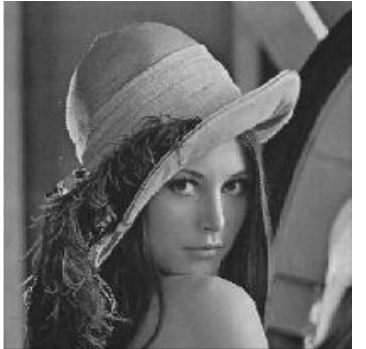

(b)

Gambar ऽ. кекоnstruksi citra menggunakan sampling window $2 \times 2$ bpp=8 dengan (a) Citra Awal "lena" berukuran $512 \times 512$ pixel (b) Citra hasil rekonstruksi "lena", $\mathrm{PSNR}=29.057$ dengan rasio kompresi $32,6 \%$

\section{Kesimpulan Dan Saran}

Pada penelitian ini berhasil dikonstruksi MP-Wavelet tipe B. Kemudian dari hasil simulasi didapatkan bahwa MP-Wavelet tipe B yang telah dikonstruksi pada penelitian ini menghasilkan rekonstruksi citra lebih baik daripada rekonstruksi menggunakan MPWavelet tipe I oleh Nobuhara dan Fahim. Pada penelitian ini untuk menganalisis sifat transformasi MP-Wavelet dilakukan secara simulasi. Untuk itu diharapkan penelitian selanjutnya agar hasilnya lebih akurat, yaitu analisis sifatnya dilakukan secara analitik. 


\section{Daftar Pustaka}

[1] Dinarina, H., Komputasi dekomposisi wavelet Haar berbasis aljabar max-plus, thesis, Jurusan Matematika FMIPA Institut Teknologi Sepuluh Nopember, Surabaya, 2011.

[2] Heijmans, H.J.M. dan Goutsias, J, Nonlinear multiresolution signal decomposition schemes - Part II: Morphological wavelets, IEEE Transaction on Image Processing 9 (11)1897-1913, 2000.

[3] Heijmans, H.J.M.,Morphological Image Operators, Academic Press, 1994.

[4] Kistosil, F. dan Mahmud, Y., Konstruksi Transformasi Wavelet Menggunakan Operator Dalam Aljabar Maxplus, Prosiding Seminar Nasional Pendidikan Sains Tahun 2014 "Inovasi Pendidikan Sains dalam Menyongsong Pelaksanaan Kurikulum 2013”, Surabaya, 2014.

[5] Loia, V. dan Sessa, S., Fuzzy relation equations for coding/decoding processes of images and videos, Information Sciences 171 145-172, 2005.

[6] Nobuhara, H. dan Pedrycz, W., Fast solving method of fuzzy relational equation and its application to lossy image compression/reconstruction, IEEE Transactions on Fuzzy Systems 8 (3) 325-334, 2000.

[7] Nobuhara,H., Trieu, D.B.K., Maruyama, T. dan Bede, B., Max-Plus algebra-based wavelet transform and their FPGA implementation for image coding, Sciencedirect Information sciences 180 3232-3247, 2010.

[8] Kistosil, F. dan Mahmud, Y., Konstruksi Transformasi MP-Wavelet Tipe A, Prosiding Seminar Nasional “Konferensi Nasional Matematika 17”, Surabaya, 2014.

[9] Subiono, Aljabar Max-plus dan Terapannya, Buku Ajar Mata Kuliah Pilihan Pasca Sarjana Matematika, Institut Teknologi Sepuluh Nopember,Surabaya, 2012.

[10] Xiang,J.Z. dan Ramadge,P.J.,Morphological Wavelets and The Complexity of Dyadic Trees, Dept of Electrical Engineering, Pricenton University, Priceton NJ, 2010.

[11] Yunus, M., Buku Ajar Mata Kuliah Analisis Wavelet, Jurusan Matematika FMIPA Institut Teknologi Sepuluh Nopember, Surabaya, 2010. 